\title{
Social determinants of infectious diseases: a public health priority
}

J C Semenza (Jan.Semenza@ecdc.europa.eu) ${ }^{1}$, J E Suk $^{1}$, S Tsolova $^{1}$

1. European Centre for Disease Prevention and Control (ECDC), Stockholm, Sweden

Citation style for this article:

Semenza JC, Suk JE, Tsolova S. Social determinants of infectious diseases: a public health priority. Euro Surveill. 2010;15(27):pii=19608. Available online: http:// www.eurosurveillance.org/ViewArticle.aspx?Articleld=19608

Vulnerable groups are disproportionately affected by infectious diseases in every European Union (EU) Member State [1]. The level and distribution of wealth within a society plays a significant role in determining vulnerabilities to communicable diseases. A clear association between social welfare spending and mortality across EU countries has been reported [2]. The current measles outbreak in Bulgaria is a stark reminder of the urgency to act on social determinants of infectious diseases in Europe [3]. Since the onset of the outbreak in April 2009, over 23,429 measles cases and 24 deaths have been reported, $90 \%$ of which have been in the Roma ethnic community [4]. The majority of cases ( $>60 \%$ ) were younger than 15 years and one third (30\%) had not received the full course of measlesmumps-rubella (MMR) vaccination (Mira Kojouharova, personal communication June 2010). A number of factors converged to precipitate this epidemic: virus importation from Germany, socio-economic and health system reform, social marginalisation, crowded living conditions and a high degree of mobility among Roma communities (Mira Kojouharova, personal communication June 2010. Such socio-economic conditions could be fertile ground for outbreaks of other vaccine-preventable diseases (e.g. diphtheria, polio), if the agents were to be introduced into these or similar communities. Indeed, social determinants of infectious diseases are a significant public health issue throughout Europe. For instance, tuberculosis (TB) prevalence in EU Member States is inversely correlated with wealth and its distribution at an ecological level (Figure): with increasing socio-economic equality, TB rates drop [5].

Thus, addressing social determinants of infectious diseases in Europe becomes a public health priority. It is not purely an issue of solidarity and social justice. Elevated infectious disease incidence/prevalence rates in vulnerable populations pose a health threat not only to them, but also to society at large: for example, high TB rates in prisons in the former Soviet Union served as a reservoir that inoculated the overall resurgence of TB in the general population [6].

The vast majority (89\%) of Europeans demand from their governments urgent actions against poverty, according to a Eurobarometer survey from 2009 [7]. The EU and its Member States have in fact committed to tackling poverty and social exclusion, yet 79 million people $-16 \%$ of Europe's population - continue to live below the poverty line (set at $60 \%$ of their country's median income) [8]. Since socio-economic inequalities lead to differential health outcomes, the strategic objectives laid down in the European Commission White Paper 'Together for health: A strategic approach for the EU 2008-2013' promote solutions to inequities in health that are linked to social, economic and environmental factors [9]; these issues are closely linked to the European Commission's overall strategic objective of Solidarity. The World Health Organization has also laid out a plan of action to tackle social determinants of health in 2008 [10]. The Portuguese EU Presidency focused on migrant health issues and, more recently, the Spanish EU Presidency embedded health inequalities in the political agenda and discussed monitoring social determinants of health, assessed progress and suggested areas of research [11]. The Belgian EU Presidency will now follow up on these initiatives with a conference on 8 and 9 November 2010, entitled 'Reducing Health Inequalities from a Regional Perspective'. The focus of the conference will be: 'What works and what does not'.

Eurosurveillance has dedicated this special issue to social determinants of infectious diseases to address some of these challenges. One paper in this issue presents different intervention strategies to reduce inequalities in infectious diseases and discusses 'what works and what does not' [12]. Two papers provide new insights about the social determinants of listeriosis $[13,14]$. While the incidence is relatively low, Europe has experienced a steady increase in incidence over the years [15]. Listeriosis is a potentially serious infection caused by consumption of food contaminated with the bacterium Listeria monocytogenes. Food products can be contaminated with Listeria during processing or preparation, and most cases are domestically acquired. L. monocytogenes is capable of multiplying in a refrigerator at $+4^{\circ} \mathrm{C}$ and as little as $100 \mathrm{cfu} / \mathrm{g}$ is considered a health risk for healthy adults, however main risk groups for listeriosis are young children, 
pregnant women, immunocompromised and elderly people $[16,17]$. While appropriate food storage is nonetheless important, especially in the home, preventing the initial food contamination is even more important.

Gillespie et al. demonstrate that human listeriosis in England is associated with neighbourhood deprivation [13]. They rank geographic areas in England according to an index of multiple deprivation (IMD) by taking into account a number of socio-economic factors: income, employment, health deprivation and disability, barriers to housing and services, living environment, crime and disorder, and education, skills and training. Listeria incidence increased with rising IMD (least to most deprived). The authors suggest that health education tailored to vulnerable groups should be intensified. Unfortunately, vulnerable groups tend not to respond well to health promotion interventions [12]. The resilience of $L$. monocytogenes to propagate even under refrigeration suggests that governments should enforce regulations for food hygiene during processing, packaging and sales to prevent contamination at the source.

The paper by Mook et al. specifically addresses pregnancy-related listeriosis among ethnic minorities in England and Wales between 2001 and 2008 [14]. The authors take advantage of a number of data sets to assess the listeriosis risk and document a significant incidence increase among ethnic minorities in recent years [14]. While ethnicity is not inevitably linked to vulnerability, ethnic minorities tended to reside more in deprived areas [18]. In light of shifting migration patterns in Europe this apparent incidence increase has an epidemic potential that should be closely monitored.

Tick-borne encephalitis (TBE) is nowadays preventable through vaccination but nevertheless has experienced

\section{FIGURE}

Wealth inequality and tuberculosis prevalence rates in the European Union ${ }^{\mathrm{a}}, 2006$

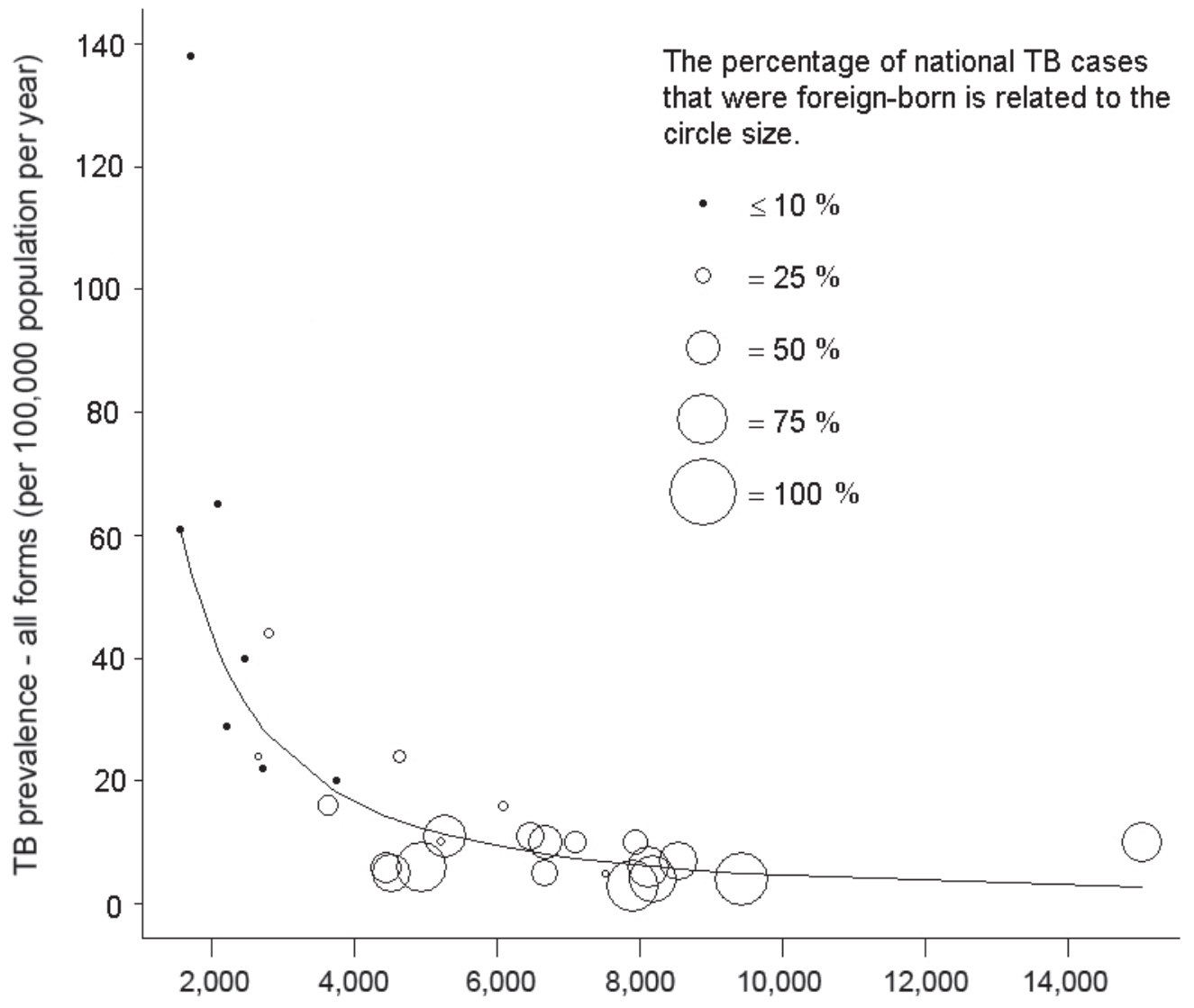

Public wealth index (GDP/income inquality)

GDP: gross domestic product; TB: tuberculosis.

a Includes 27 EU Member States plus Norway and Iceland.

The Public Wealth Index divides a nation's economic wealth (as measured with Eurostat data on GDP in Purchasing Power Standards per capita) by its level of social cohaesion (using Eurostat's inequality of income distribution ratio). Effectively, this metric takes the relative high level of wealth in Europe into account while also controlling for its distribution. It favours very wealthy countries with low income inequality ratios: the top five scores on the public wealth index were generated by Luxembourg, Norway, Denmark, Sweden and the Netherlands.

Reproduced from Suk J, Manissero D, Büscher G and Semenza JC. Wealth inequality and TB elimination in Europe. Emerging Infectious Diseases. 2009;15(11):1812-4 [5]. 
an upsurge in Europe in recent years, with cases reported from new areas, including Norway and some parts of Germany that had not previously reported TBE $[19,20]$. Previous studies have shown that factors such as climate variations that directly or indirectly influence the transmission of the virus, the vector, the vertebrate wildlife, or people's behaviour, are correlated with variations of TBE incidence over time [21]. An article by Randolph et al. in this issue of Eurosurveillance proposes that during periods of rapid political change, socio-economic factors will play a prominent role in changing disease risk [22]. In the early 1990s, following political independence from the former Soviet Union, TBE rates surged in most central and eastern European (CEE) countries.

The studies summarised in Randolph et al. suggest strong correlations across eight CEE countries between TBE rates and the percentage of household expenditure on food. Randolph suggests mushroom picking as an alternative source of income in times of high unemployment as a driver of these rates. In Latvia, higher TBE rates were observed after forest cutting activities (probably through exposure of forest workers), at times of low economic activity (in a national level analysis), or in populations with low education levels (in a regional level analysis). Weather patterns are also described to play a role in determining human exposure to ticks, whether related to mushroom foraging or to recreational activities. These intriguing suggestions call for epidemiologic case control studies to account for potential confounders. Such studies would truly advance the field. For example, Randolph points out, in line with previous studies, that under more stable socio-economic conditions, TBE emergence may rather be the consequence of enhanced zoonotic cycles.

Today, in the wake of the financial crisis, rising unemployment and public debt in many EU countries lend further weight to the notion emphasised in all papers in this issue: socio-economic determinants of infectious diseases are a public health priority, perhaps even more urgently now than in recent times.

\section{References}

1. Semenza JC, Giesecke J. Intervening to reduce inequalities in infections in Europe. Am J Public Health. 2008;98(5):787-92.

2. Stuckler D, Basu S, McKee M. Budget crises, health, and social welfare programmes. BMJ. 2010 Jun 24;340:C3311.

3. Marinova L, Kojouharova M, Mihneva Z. An ongoing measles outbreak in Bulgaria, 2009. Euro Surveill. 2009;14(26):pii=19259. Available from: http://www. eurosurveillance.org/ViewArticle. aspx?Articleld $=19259$

4. National Center of Infectious and Parasitic Diseases, Ministry of Health, Bulgaria. Homepage on the internet. Available from: http://www.ncipd.org/

5. Suk J, Manissero D, Büscher G, Semenza JC. Wealth inequality and TB elimination in Europe. Emerg Infect Dis. 2009;15(11):1812-4.

6. Shilova MV, Dye C. The resurgence of tuberculosis in Russia. Philos Trans R Soc Lond B Biol Sci. 2001;356(1411):1069-75.
7. Commission of the European Communities. Eurobarometer survey on poverty and social exclusion. Brussels: Commission of the European Communities; 2009. ISBN 978-92-79-13668-9. doi: 10.2767/5244. Available from: http://www.2010againstpoverty.eu/extranet/ Eurobarometre 150DPI_091113.pdf

8. Commission of the European Communities. 2010, the European Year for combating poverty and social exclusion. Brussels: Commission of the European Communities. Available from: http://www.2010againstpoverty.eu/extranet/About_the_Year/ factsheet_EY2010_en.pdf

9. Commission of the European Communities. White paper. Together for Health: A strategic approach for the EU 2008-2013. Brussels (Belgium): Commission of the European Communities; 23 October 2007. Available from: http://ec.europa.eu/health/ph_overview/Documents/ strategy_wp_en.pdf

10. Commission on Social Determinants of Health. Closing the gap in a generation: health equity through action on the social determinants of health. Final Report of the Commission on Social Determinants of Health. Geneva: World Health Organization; 2008. Available from: http://www.who.int/ social_determinants/thecommission/finalreport/en/index.html

11. Technical Committee for the priority of the Spanish Presidency on "Monitoring Social Determinants of Health and the Reduction of Health Inequalities". General Directorate for Public Health and International Health. Ministry of Health and Social Policy, Madrid, Spain. Reducing health inequalities and monitoring social determinants of health in the European Union: a priority of the Spanish Presidency of the European Union 2010 . Euro Surveill. 2010;15(27):pii=19612. Available from: http://www.eurosurveillance.org/ViewArticle. aspx?Articleld $=19612$

12. Semenza JC. Strategies to intervene on social determinants of infectious diseases. Euro Surveill. 2010;15(27):pii=19611. Available from: http://www.eurosurveillance.org/ViewArticle. aspx?Articleld $=19611$

13. Gillespie IA, Mook P, Little CL, Grant KA, McLauchlin J. Human listeriosis in England, 2001-2007: association with neighbourhood deprivation. Euro Surveill. 2010;15(27):pii=19609. Available from: http://www. eurosurveillance.org/ViewArticle.aspx?Articleld=19609

14. Mook P, Grant KA, Little CL, Kafatos G, Gillespie IA. Emergence of pregnancy-related listeriosis amongst ethnic minorities in England and Wales. Euro Surveill. 2010;15(27):pii=19610. Available from: http://www.eurosurveillance.org/ViewArticle. aspx?Articleld $=19610$

15. European Centre for Disease Prevention and Control. Annual Epidemiological Report on Communicable Diseases in Europe 2009. Stockholm: European Centre for Disease Prevention and Control; October 2009. Available from: http://www.ecdc. europa.eu/en/publications/Publications/o910 SUR Annual Epidemiological_Report_on_Communicable_Diseases_in_ Europe.pdf

16. Miettinen MK, Siitonen A, Heiskanen P, Haajanen $H$, Björkroth KJ, Korkeala HJ. Molecular epidemiology of an outbreak of febrile gastroenteritis caused by Listeria monocytogenes in cold-smoked rainbow trout. J Clin Microbiol. 1999;37(7):2358-60.

17. The Community summary report on trends and sources of zoonoses and zoonotic agents in the European Union in 2007. The EFSA Journal. 2009;223. Available from: http://www.efsa. europa.eu/EFSA/efsa_locale-1178620753812_1211902269834. htm

18. Tinsley J, Jacob M. Deprivation and Ethnicity in England: A Regional Perspective. Regional Trends 2006;39:19-28.

19. Skarpaas T, Golovljova I, Vene S, Ljøstad U, Sjursen H, Plyusnin A, et al. Tickborne encephalitis virus, Norway and Denmark. Emerg Infect Diseases. 2006;12(7):1136-8.

20. Süss J, Schrader C, Falk U, Wohanka N. Tick-borne encephalitis (TBE) in Germany--epidemiological data, development of risk areas and virus prevalence in field-collected ticks and in ticks removed from humans. Int J Med Microbiol. 2004;293 Suppl 37:69-79.

21. Lindgren E. Climate and tickborne encephalitis. Conservation Ecology [online]. 1998;2(1):5. Available from: http://www. consecol.org/vol2/iss1/art5

22. Randolph SE, on behalf of the EDEN-TBD sub-project team. Human activities predominate in determining changing incidence of tick-borne encephalitis in Europe. Euro Surveill. 2010;15(27):pii=19606. Available from: http://www. eurosurveillance.org/ViewArticle.aspx?Articleld=19606 